\title{
Role of vitamins and minerals as immunity boosters in COVID-19
}

\author{
Puneet Kumar ${ }^{1}\left(\right.$ Mandeep Kumar $^{2} \cdot$ Onkar Bedi $^{3} \cdot$ Manisha Gupta $^{3} \cdot$ Sachin Kumar ${ }^{4}$ - Gagandeep Jaiswal ${ }^{4}(1)$. \\ Vikrant Rahi ${ }^{4} \cdot$ Narhari Gangaram Yedke $^{4} \cdot$ Anjali Bijalwan $^{1} \cdot$ Shubham Sharma ${ }^{1} \cdot$ Sumit Jamwal ${ }^{5}$
}

Received: 28 April 2021 / Accepted: 29 May 2021 / Published online: 10 June 2021

(c) Springer Nature Switzerland AG 2021, corrected publication 2021

\begin{abstract}
Severe acute respiratory syndrome coronavirus-2 (SARS-CoV-2) known as coronavirus disease (COVID-19), emerged in Wuhan, China, in December 2019. On March 11, 2020, it was declared a global pandemic. As the world grapples with COVID-19 and the paucity of clinically meaningful therapies, attention has been shifted to modalities that may aid in immune system strengthening. Taking into consideration that the COVID-19 infection strongly affects the immune system via multiple inflammatory responses, pharmaceutical companies are working to develop targeted drugs and vaccines against SARSCoV-2 COVID-19. A balanced nutritional diet may play an essential role in maintaining general wellbeing by controlling chronic infectious diseases. A balanced diet including vitamin A, B, C, D, E, and $\mathrm{K}$, and some micronutrients such as zinc, sodium, potassium, calcium, chloride, and phosphorus may be beneficial in various infectious diseases. This study aimed to discuss and present recent data regarding the role of vitamins and minerals in the treatment of COVID-19. A deficiency of these vitamins and minerals in the plasma concentration may lead to a reduction in the good performance of the immune system, which is one of the constituents that lead to a poor immune state. This is a narrative review concerning the features of the COVID-19 and data related to the usage of vitamins and minerals as preventive measures to decrease the morbidity and mortality rate in patients with COVID-19.
\end{abstract}

Keywords COVID-19 $\cdot$ Corona virus $\cdot$ Minerals $\cdot$ Therapy $\cdot$ Vitamin

\section{Introduction}

Coronavirus is the cause of newly discovered infectious diseases known as COVID-19. The clinical features of COVID19 are similar to previous outbreaks reported in the 21st century, the Middle East respiratory syndrome (MERS) and Severe acute respiratory syndrome (SARS) (Rothan

Puneet Kumar

punnubansal79@gmail.com; Puneet.bansal@cup.edu.in

1 Department of Pharmacology, Central University of Punjab, Ghudda-151401, Bathinda, Punjab, India

2 Department of Pharmacology and Toxicology, University of Genoa, Genoa, Italy

3 Chitkara College of Pharmacy, Chitkara University, Punjab, India

4 Department of Pharmaceutical Sciences and Technology, Maharaja Ranjit Singh Punjab Technical University, Bathinda, India

5 Department of Psychiatry, Yale School of Medicine, Yale University, New Haven, CT 06511, USA and Byrareddy 2020). Both SARS and MERS were said to emerge in bats and transmit to humans (Derbyshire and Delange 2020; Tay et al. 2020). On December 31, 2019, the World Health Organization (WHO) announced that SARSCoV-2 is responsible for COVID-19 and on March 11, 2020, it was declared a global pandemic. The primary site of action of COVID- 19 is the human respiratory system (Rothan and Byrareddy 2020), although other organ systems are also involved. An initial sign of pneumonia of an unknown etiology was diagnosed in a clump of epidemiologically linked patients to Wuhan, Hubei Province, China. Other symptoms include fever, dry cough, dyspnoea, sore throat, headache, dizziness, generalized weakness, vomiting and diarrhea were observed (Shakoor et al. 2020a). It is now well recognized that COVID-19 has complex respiratory symptoms ranging from minimal signs to hypoxia with acute respiratory distress syndrome (ARDS) (Rothan and Byrareddy, 2020). Angiotensin-converting enzyme2 (ACE2) receptor is utilized to invade SARS-CoV-2 into human cells (Yazdanpanah and Hamblin 2020; Zabetakis et al. 2020). 
Epidemiology data of COVID-19 show that the outbreak rate is often more severe among above 60 years older people or who have health conditions like lung or heart disease, diabetes. Children below the age of 10 are affected but not at high rates as the percentage is very low. Although no gender was predominantly seen, males outnumbered females due to smoking and drinking habits (Yuki et al. 2020). The daily report shows the steep elevation in new cases from different regions/countries (Tay et al. 2020). There is no registered treatment for COVID-19 due to a lack of in-depth knowledge about the pathogen to host response (Shakoor et al. 2020b; Tay et al. 2020). Remdesivir is the only FDA-approved treatment in the US for COVID-19 patients and in a highly selected group. It is now used for hospitalized patients of every age group with severe conditions (Michienzi and Badowski 2020). Two important steps in battling COVID-19 infection are proper nutrition and activation of the immune system to fight against the disease (Derbyshire and Delange 2020). Scientists are working around the clock to find a suitable cure, and till then, it is our prime duty to be safe and not compromise our health and increase the risk of COVID-19. Several vitamins and trace elements may play critical functions in strengthening the immune system and decreasing infections.

The primary goal of this review is to highlight the potential therapeutic role of vitamins A, B, C, D, E and K, along with micronutrients as an immunity booster in COVID-19 patients.

\section{Immunity and COVID-19}

COVID-19 is omnipresent; since the onset of the COVID-19 outbreak, fear and panic have traveled globally. This virus plays with an individual's immunity, i.e., the severity of the infection depends on one's immuno-competence; every individual has a different kind of immune system, with their daily activity significantly impacting the immune system's strength (Michienzi and Badowski 2020).

The SARS-CoV-2 virus can bind to ACE2 expressing cells present in orals tissues, especially in alveolar lung cells, bronchial epithelium, and vascular endothelial cells. In the lungs, the infection cause downregulation of ACE2 receptors and RAS dysfunction, causing acute lung injury (Tay et al. 2020) (Ni et al. 2020). RAS dysfunctions trigger the release of various Proinflammatory mediators such as interleukins and cytokines (Yuki et al. 2020). This elevation leads to dysregulation of the host immune system (Shakoor et al. 2020a, b). People with a robust immune system can fight back the infection. However, the reasons behind the decline in immunity were proposed to be inflammation, improper functions of $\mathrm{T}$ cells, due to dietary imbalance lack of micro and macro nutrients (Derbyshire and Delange 2020).

\section{Introduction to vitamin as an immunity booster}

It is well established that nutritional deficiency can impair and adversely affect one's immune system by infections. Recent evidence has highlighted the role of nutritional supplementation, and if administered in higher than recommended daily doses, it might be beneficial in potentially reducing viral load and hospitalization for COVID19 patients. Vitamins are essential dietary components because of their antioxidant properties and immunomodulatory effects (Shakoor et al. 2020b). Some of them regulate gene expression in immune cells and support the maturation and differentiation of immune cells. The vitamins $\mathrm{C}$ and $\mathrm{E}$ act as powerful antioxidants in combatting free radical species (Gombart et al. 2020). It was scientifically documented that body may be deprived of these nutrients, vitamins, and minerals while fighting against infections due to the demand for activation energy for the immune stimulation, by a stressful lifestyle, diseases like viral infection, diabetes, obesity, which directly affects the nutrients status (Gombart et al. 2020). Clinical trials and associated interventions for vitamins are shown in Table 1.

\section{Role of vitamin A in COVID-19}

Vitamin A belongs to the family of retinyl-esters and is also known as retinoic acid (RA) (Gudas 2012), which controls the various genes involved in innate and adaptive immune responses (Raverdeau and Mills 2014). Vitamin A acts as T-cell effectors, facilitating adaptive and innate immunity (Raverdeau and Mills 2014). Retinoid directly stimulates the expression of Interferon stimulated genes (ISGs), including retinoic acid-inducible gene I (RIG-I) and IFN regulatory factor 1 (IRF-1) (Matikainen et al. 1996; Lindner et al. 1997; Luo and Ross 2006).

Several studies showed the protective effect of natural and synthetic retinoids on some viruses such as hepatitis $\mathrm{B}$ virus (HBV), influenza, norovirus, $\mathrm{MeV}$, and cytomegalovirus (Angulo et al. 1998; Trottier et al. 2008; Lee and Han 2016; Li et al. 2018). A study conducted by Yuan et al showed the significant effect of Am580. It is an agonist of RAR- $\alpha$ against, it acts on MERS-CoV and SARS-CoV through interruption of lipogenic pathways mediated by SREBP (Yuan et al. 2019). It was determined that coronavirus SARS-CoV and MERS-CoV could stop the antiviral responses mediated by IFN-I and probably delay treatments (Spiegel et al. 2005; Frieman et al. 2007; Yang et al. 2015; Hu et al. 2017). A study revealed that IFN-I signaling significantly increases by retinoids (Gudas 2012), 
which permits the pre-clinical testing of retinoids and IFN-I combination in both in vivo and in vitro models.

\section{Role of vitamin B in COVID-19}

Vitamin B is a naturally occurring component and is known to be involved in Red blood cells (RBC) production. All the vitamins under the $\mathrm{B}$ complex category are important for the body cells' normal physiological functioning (Zhang et al. 2018). Vitamin B supports the body to use energy-yielding nutrients (such as carbohydrates, fat, and protein) for sustaining healthy skin and brain cells and some other tissues. Vitamin B complex comprises a total of 8 vitamins, i.e., thiamine [B1], riboflavin [B2], niacin [B3], pantothenic acid [B5], pyridoxine [B6], biotin [B7], folate, or folic acid [B9], cyanocobalamin [B12]. It plays an essential role in colonic immune regulation and contributes to intestinal barrier function. (Lindschinger et al. 2019).

\section{Vitamin B1 (thiamine)}

Thiamine is a coenzyme aids in the generation of energy for the body, maintains a constant temperature, and is implicated in fat synthesis, and is necessary for the nervous and immune system functioning (Kraft and Angert 2017). It has been reported that vitamin B1 has a potential anti-inflammatory effect while acting on macrophages, and it suppresses oxidative stress evoked NF-kappa B activation (Spinas et al. 2015). Thiamine deficiency affects the immune system due to various pathological initiations like increased inflammation, oxidative stress,

metabolic disturbances, which further leads to the production of aberrant antibodies (Mikkelsen and Apostolopoulos 2019) It was documented that thiamine plays a significant role in eliminating the SARS-CoV-2 virus by triggering humoral and cell-mediated immunity. Hence, sufficient levels of thiamine help in building immunity against SARSCoV-2 patients (Shakoor et al. 2020b).

\section{Vitamin B2 (riboflavin)}

Vitamin B2 is a neuroactive compound with immunomodulatory impressions, and its insufficiency provides a proinflammatory gene expression pattern. It has been found that riboflavin provides a shielding effect versus liver damage induced through CCL4, arbitrated by TNF, in experimental animal models, intimating that it can be employed as a hepato-protective agent (Yoshii et al. 2019). Riboflavin with UV light causes irreversible damage to nucleic acids leading to inhibition of replication of pathogens. Hence, it can be used to reduce pathogens in the blood plasma of COVID-19 patients to reduce the risk of transfusion-transmission of COVID-19.

\section{Vitamin B3 [niacin (nicotinic acid, pantothenic acid)]}

Niacin has extensive modulatory effects on the generation of inflammatory mediators and the immune cell movement. Hence, it has an anti-inflammatory impact, though its effects have not been thoroughly explained. It restrains CXC chemokine, CXCL-8/IL-8 induction, neutrophil migration induced by lipid mediator leukotriene (LT) B4 (in mice), and adherence (Shibata et al. 2017). It has been found to decrease IL-6, IL- $1 \beta$, and TNF- $\alpha$ in stimulated alveolar macrophages. Recent data indicate that targeting IL- 6 could reduce inflammation in COVID-19 patients (Liu et al. 2020).

Furthermore, niacin acts as an anti-inflammatory agent; it reduces neutrophil infiltration in patients with ventilatorinduced lung injury (Nagai et al. 1994). The other scientific report described that nicotinamide reduces viral infection and stimulates defense mechanisms. Considering the therapeutic features of niacin, it can be used as an adjunct in the therapy of COVID-19 patients (Mehmel et al. 2020).

\section{Vitamin B6 (pyridoxine)}

Vitamin B6 influences innate/adaptive immunity, function, and proliferation of immune cells (Ueland et al. 2017). Persons with vitamin B6 deficiency were found with the inhibition of cytokine/chemokine release. Studies suggest that vitamin B6 mediates the cellular immune response by activating the IFN-gamma (Parra et al. 2018). A recent study revealed that pyridoxine supplement helps to relieve COVID-19 symptoms by improving immune responses, reducing pro-inflammatory cytokines, supporting endothelial integrity, and preventing hypercoagulability.

\section{Vitamin B9 (folic acid, folate)}

Folate is an essential vitamin for DNA and protein synthesis and also plays an important role in the adaptive immune response. A recent study determined that folic acid inhibits the furin, an enzyme responsible for bacterial and viral infections, and blocks the binding of SARS-CoV-2 spike protein. Therefore in the early stages, folic acid could be useful for controlling COVID-19-associated respiratory disease (Sheybani et al. 2020). A recent study reported that folic acid and its derivatives, 5-methyl tetrahydrofolic acid, and tetrahydrofolic acid have a strong affinity against the SARSCoV-2 (Kumar and Jena 2020). 


\section{Vitamin B12 (cobalamin/cyanocobalamin)}

Vitamin B may regulate chemokine/cytokine formation and arbitrate the intercommunication with immune cells implicated in pathophysiological pathways. Thus, it is recommended that it can protect against various bacterial and viral infections. Furthermore, as it also plays an essential role in colonic immune regulation and contributes to intestinal barrier function, it might play a crucial role in the immunity and protection against coronavirus (COVID-19) as there is proof that probiotics such as bifidobacterial and lactobacilli can modulate the immune response and protect against infections, including respiratory tract infections (Calder et al. 2020).

\section{Role of vitamin C in COVID-19}

Vitamin $\mathrm{C}$ is well known for its antiviral properties, such as increasing the interferon-alpha production, modulating cytokines, reducing inflammation, improving endothelial dysfunction, and restoring mitochondrial function (Carr and Maggini 2017; Dey and Bishayi 2018). In the early 30s and 70s, Linus Pauling (Nobel Prize winner) stated the beneficial effect of vitamin $\mathrm{C}$ in the common cold (Heikkinen and Järvinen 2003). There is also some evidence that showed the viricidal property of vitamin C (Furuya et al. 2008). Vitamin C supports the immune system to fight against bacterial and viral infections. It helps to eliminate the dead cells and replace them with new cells (Ekert and Vaux 1997; Carr and Maggini 2017). The antioxidant property of vitamin $\mathrm{C}$ protects the damage induced by oxidative stress.

Several studies showed that vitamin C supplementation reduces the risk associated with upper respiratory tract infections (Carr and Maggini 2017). A review published by Hemila et al. confirmed that daily $1-2 \mathrm{~g}$ of vitamin $\mathrm{C}$ reduced the symptoms of common cold both in adults and in children (Hemilä and Chalker 2013). Intravenous administration of vitamin $\mathrm{C}$ significantly reduces severe infections, such as sepsis and acute respiratory distress syndrome (ARDS) (Kashiouris et al. 2020). There is some indirect and direct evidence that reveals vitamin C's effectiveness in treating patients with COVID-19. One Cochrane review and a randomized controlled trial showed a significant reduction in the common cold symptoms by oral administration of $0.2 \mathrm{~g} /$ day vitamin C. One trial on adult patients showed a dose-dependent decrease in the duration of pneumonia with two vitamin $\mathrm{C}$ doses (Baladia et al. 2020). Therefore, research addressing vitamin C's role specifically for COVID-19 would add helpful information (Carr 2020).

\section{Role of vitamin D in COVID-19}

Vitamin D is a secosteroid with anti-inflammatory and antioxidant properties. It helps to maintain the calcium-phosphorus metabolism. A number of studies suggested that vitamin D inhibits the overexpression of inflammatory cytokines such as IL- $1 \alpha$, IL- $1 \beta$, tumor necrosis factor- $\alpha$ (Hughes and Norton 2009). It is also involved in the modulation of the immune response in infectious and autoimmune diseases. The sunlight emits ultraviolet $\mathrm{B}$ radiation, which is absorbed in the skin and leads to the conversion of 7-dehydrocholesterol into cholecalciferol. As dietary sources did not provide a sufficient amount of vitamin D. Therefore, fortification of oral supplementation is often necessary. The new investigation revealed that the cities' temperature and latitude affected by COVID-19 are similar to those of the most affected areas (Sajadi et al. 2020). This is an essential factor because people have a low vitamin $\mathrm{D}$ concentration in high-latitude countries (Cannell et al. 2006). Previously, vitamin D insufficiency was reported in patients from high alert areas. Furthermore, the prevalence of vitamin D deficiency varies among several geographical regions of each country, limiting our ability to simplify the results.

\section{Vitamin D for respiratory tract infections}

Literature has demonstrated that vitamin D insufficiency can lead to respiratory tract infection (Lemire 1992). Therefore, vitamin D has been widely investigated as a therapeutic agent for acute respiratory tract infections (ARTIs). A study conducted by Xu et al. reported the protective effect of calcitriol (vitamin D agonist) against acute lung injury by modulating the expression of ACE2 in lung tissue (Xu et al. 2017), which is one of the pathogenic factors in COVID-19. Some studies showed significant results with a high dose of 250,000-500,000 IU.

Vitamin D is associated with a decreased hospital stay, improved blood oxygen level, and increased hemoglobin levels (Han et al. 2016). Studies reported that persons with a vitamin D level of more than $95 \mathrm{nmol} / \mathrm{L}$ have a low risk of acute viral respiratory tract infections as compared with the patients with lower than $95 \mathrm{nmol} / \mathrm{L}$ (Sabetta et al. 2010). A recent meta-analysis demonstrated that supplementation of vitamin D decreased the risk of acute respiratory tract infections as compared to those with low levels of vitamin $\mathrm{D}$ at baseline $(<25 \mathrm{nmol} / \mathrm{L})$ (Martineau et al. 2017).

\section{Vitamin D for microbial infections}

Several mechanisms are reported to be involved through which vitamin $\mathrm{D}$ helps reduce microbial infections and 
death. A review reported the agency of vitamin D against the common cold in three classes: physical barrier, natural cellular immunity, and adaptive immunity (Rondanelli et al. 2018). Vitamin D also improves innate cellular immunity by induction of antimicrobial peptides, such as cathelicidin and defensins (Laaksi 2012). This has direct antimicrobial actions against several bacteria, viruses and fungi (Herr et al. 2007). A clinical trial published that 4000 IU/day of vitamin D significantly decreased dengue infection. (MartínezMoreno et al. 2020).

Vitamin D is also known to reduce the pro-inflammatory cytokine level, such as tumor necrosis factor, interferon, and increase anti-inflammatory cytokine (Sharifi et al. 2019; Huang et al. 2020). Vitamin D supplementation enhances cellular immunity and improves glutathione production (Lei et al. 2017, Colunga et al. 2020) and has been suggested to prevent and treat COVID-19 (Wimalawansa 2020). Furthermore, on 23rd March 2020, Dr. Tom Frieden, the former director of the Centre for Disease Control and Prevention, recommended vitamin D to fight the COVID-19.

\section{Role of vitamin E in COVID-19}

Vitamin E plays a crucial role in regulating and supporting immune system function as a potent antioxidant (Jayawardena et al. 2020). Vitamin E acts as a free radical scavenger, reduces oxidative stress, and prevents free radicals containing unshared electrons and highly energetic and damaged cells. Unshared electrons form reactive oxygen species (ROS) with rapidly reacting with oxygen. (Verhagen et al. 2006). Other than antioxidant and anti-inflammatory properties, vitamin $\mathrm{E}$ also has a function in immunity. Alphatocopherol is an inhibitor of protein kinase $\mathrm{C}$, cell proliferation and differentiation in smooth muscle cells, monocytes and platelets. Vitamin E also increases the level of prostacyclin by inhibiting the metabolism of arachidonic acid which results in dilation of blood vessels and inhibition of platelet aggregation (vitamin E-Health Professional Fact Sheet). A study reported that increased intake of vitamin $\mathrm{E}$ is more beneficial in maintaining immunity function in elderly individuals as compared to younger individuals (Hemila 2016; Meydani et al. 2018).

\section{Role of vitamin K in COVID-19}

Vitamin $\mathrm{K}$ is a fat-soluble vitamin, belongs to the family of 2- methyl-1,4-naphthoquinone (Booth 2012). It is naturally present in some foods and also available as a dietary supplement in two forms: K1 (phylloquinone) and K2 (including different menaquinones, MKs) (Hubicka et al. 2020).
Vitamin $\mathrm{K}$ is a co-factor and functions as a co-enzyme involved in hemostasis by synthesizing protein and other physiological functions (Janssen and Walk 2020). At times of insufficiency of vitamin $\mathrm{K}$ hepatic factor, coagulation factors over extrahepatic ones are predominant. Matrix Gla protein (MGP), a vitamin K-dependent protein, is soft tissue mineralization and elastic fiber degradation inhibitor. To protect the pulmonary extracellular matrix from degradation induced by inflammation, there is an increase in the synthesis of Matrix Gla protein (MGP) in the lungs of SARSCoV-2 patients, which promotes the utilization of vitamin $\mathrm{K}$ from extrahepatic vitamin $\mathrm{K}$ stores (Mccann and Ames 2020). COVID-19 may affect venous and arterial thromboembolic disease due to extreme inflammation, hypoxia, immobilization, and diffuse intravascular coagulation (DIC). It can also cause blood clotting and leads to the degradation of elastic fibers in the lungs. As vitamin K1 is responsible for the activation of hepatic coagulation factors, thus it helps combat thrombotic complications in COVID-19 patients (Klok et al. 2020).

\section{Role of minerals as immunity boosters in COVID-19}

\section{Role of macrominerals in COVID-19}

Considering the outcomes of COVID-19 infection, In the absence of effective treatment, a strong immune system is one of the most effective defense mechanisms. Moreover, supplementation of minerals has positively impacted immunity in viral infections (Jayawardena et al. 2020). Minerals are inorganic substances required by the body to support body functions. Minerals are involved in various physiological processes such as bone development, blood formation, hormone synthesis, and regulation of heartbeat. The role of macro minerals are described individually in Table 2 (Romita and O'Brien 2018). Many epidemiological studies have demonstrated that low intake of essential minerals in diet plays a crucial role in preventing and reducing cardiovascular and cerebrovascular diseases, which may be involved in the progression of corona infections (Zabetakis et al. 2020).

In early COVID-19 studies, some data have been given that show how the presence and absence of minerals in the body are considered essential in regulating the expression of angiotensin-converting enzyme-2 (ACE2) in boosting the immune system. ACE-2 receptors are the coronavirus' main targets for its entry into the respiratory system and badly affect this system (Ivanov et al. 2020). Also, an animal study showed that mineral deficiency could increase the expression of ACE2 through the activation of RAAS. Therefore, we could consider that the long-term mineral deficiency may increase the level of ACE2 in lower respiratory tract cells, 


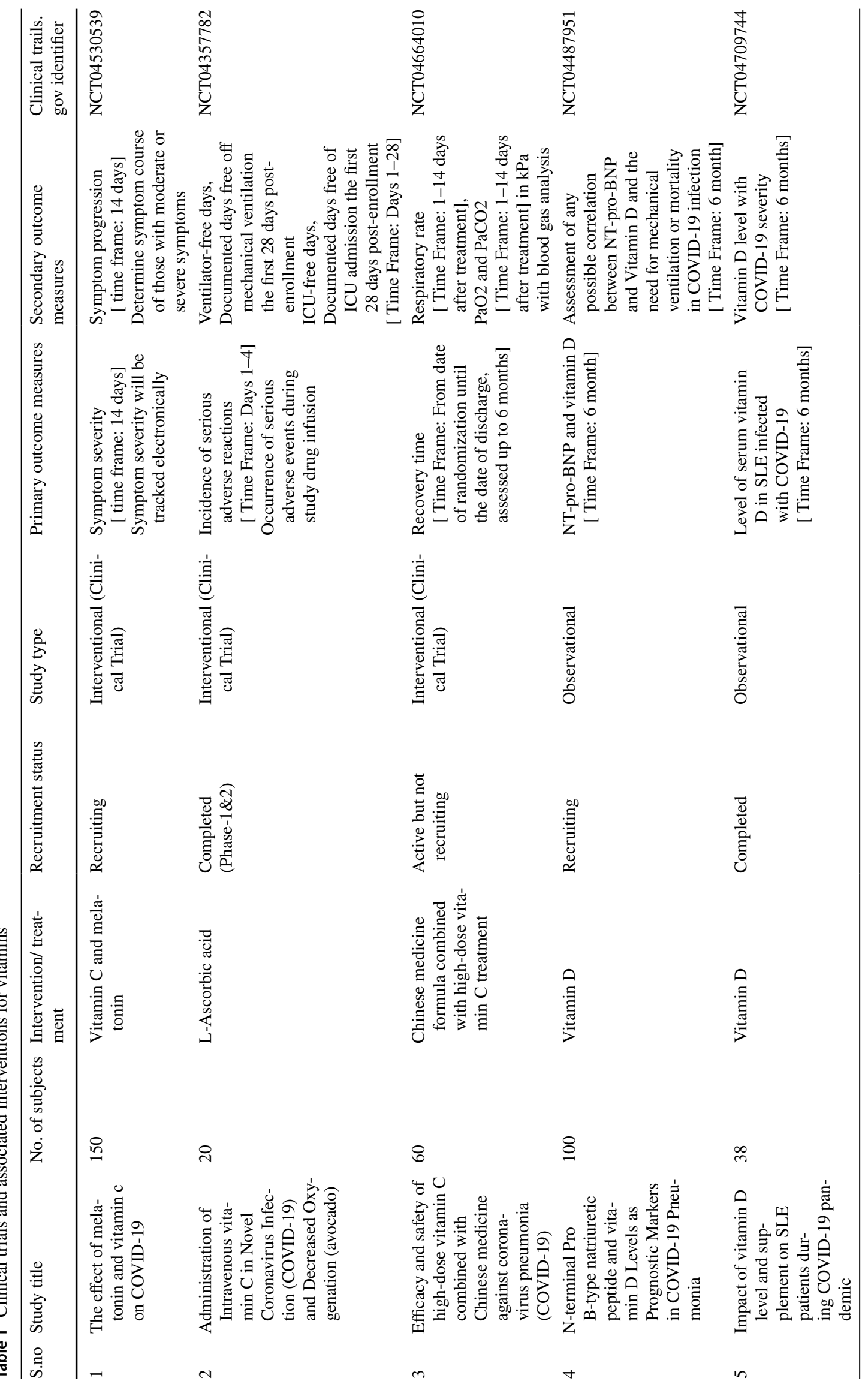




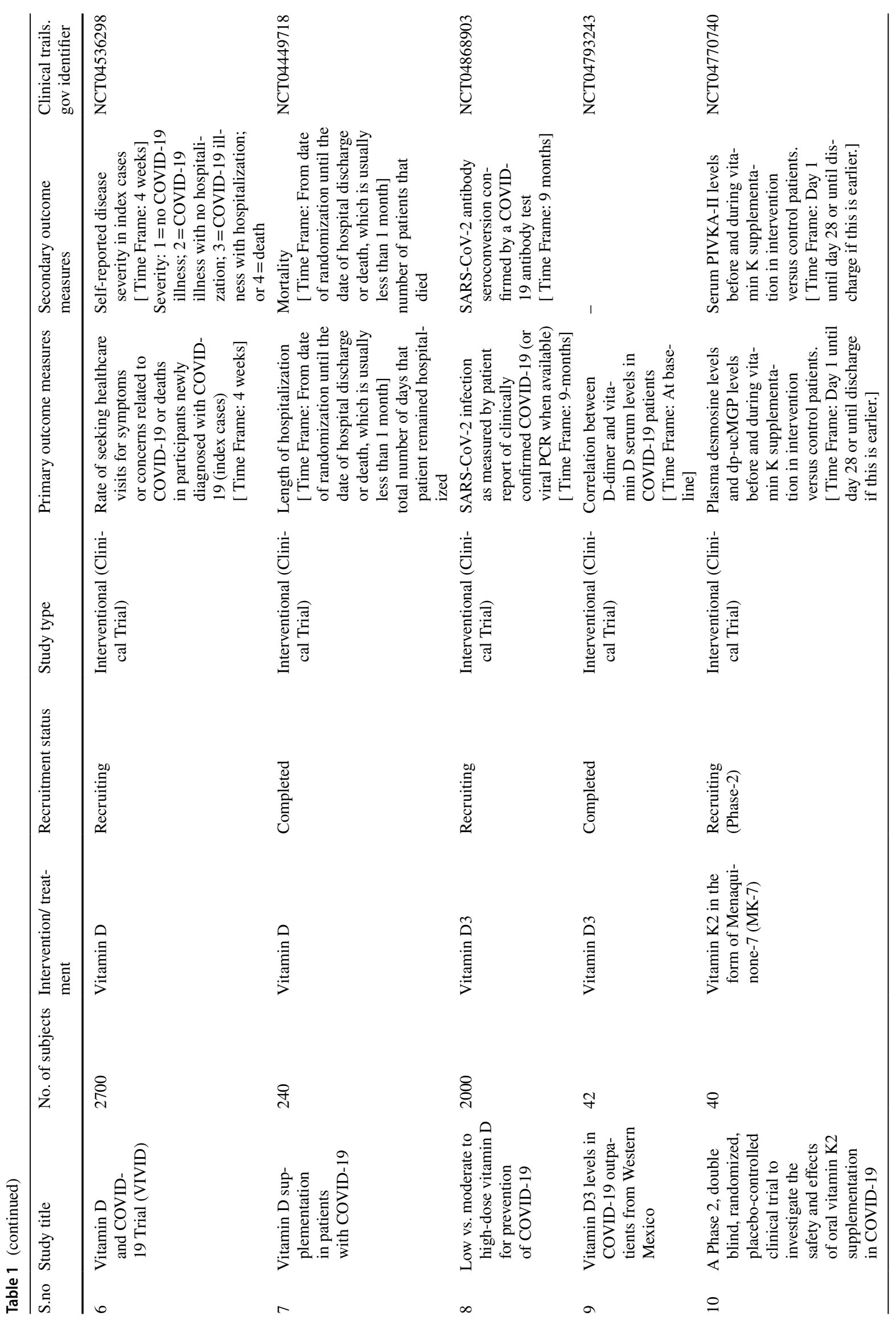




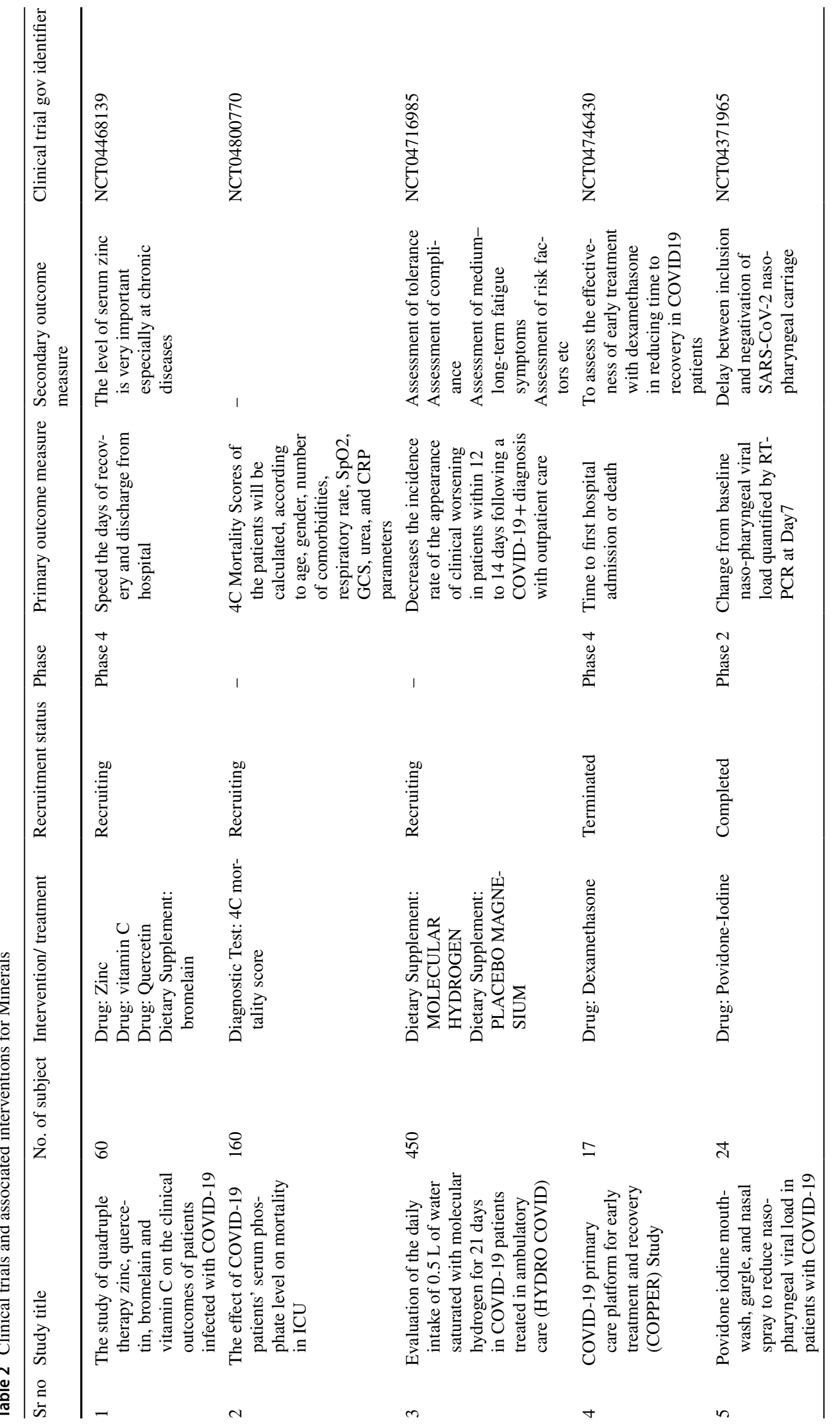




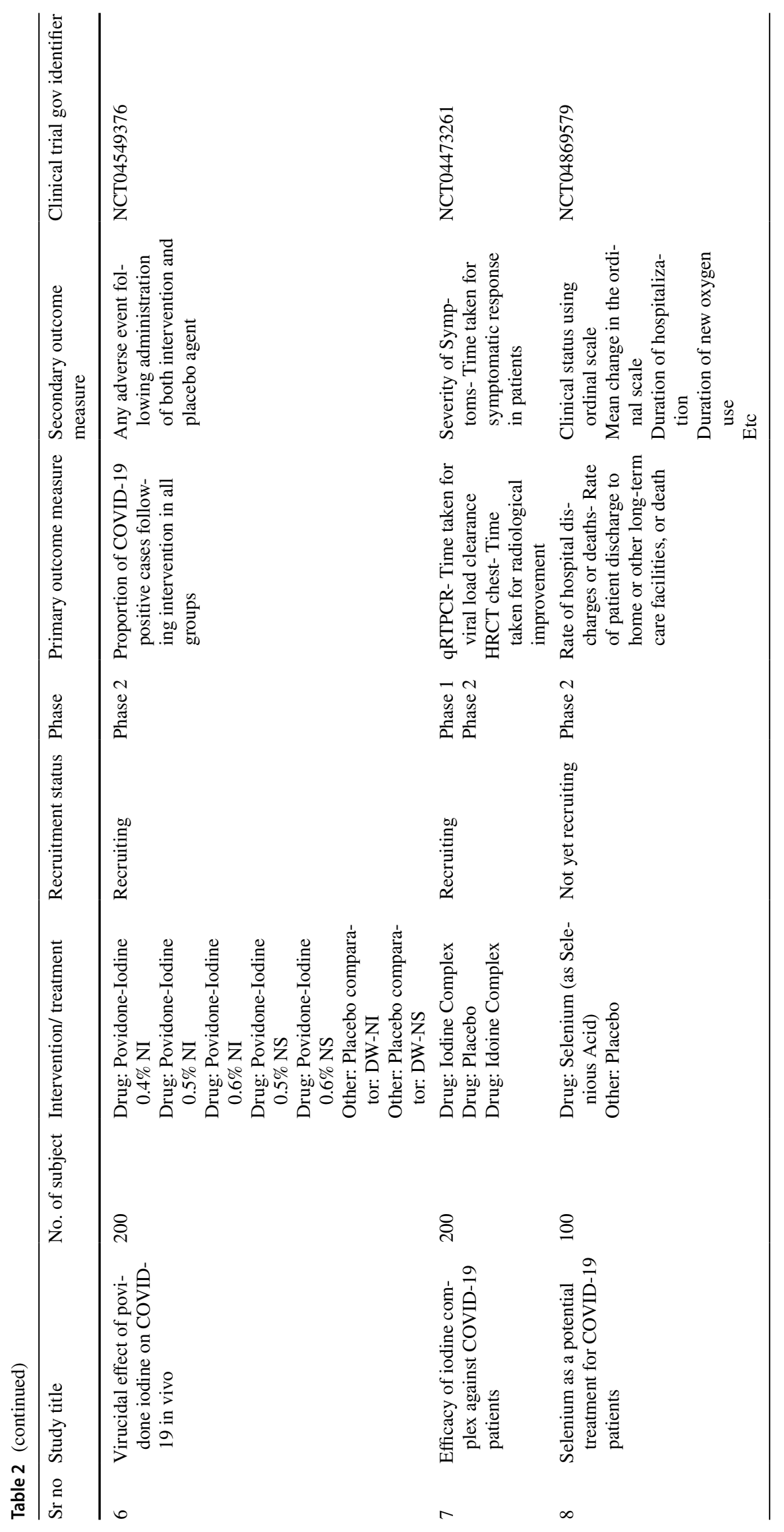


which would increase the sensitivity and pathogenicity of SARS-CoV-2 infection (Cole-Jeffrey et al. 2015; Gheblawi et al. 2020). The low availability of the minerals affects our immune system, which triggers various pathogenic infections. Further disclosure about each mineral may help us approach stronger immunity, thus preventing the body from such infections (Gombart et al. 2020).

\section{Sodium}

Sodium plays a significant role in the regulation of electrolytic balance and the expression of ACE2 in SARS-CoV-2 (Luo et al. 2020). In a meta-analysis, it was found that sodium concentration significantly decreases in COVID-19 patients. A study in the US reported the serum sodium concentration of COVID-19 patients as $136.0 \mathrm{mmol} / \mathrm{L}$, which was less than the normal level, i.e., $138.0 \mathrm{mmol} / \mathrm{L}$ (Habib et al. 2020). Another study has also reported that sodium level decreases with the increase in severity of disease (Lippi et al. 2020). Such hyponatremia may be associated with SARS-CoV-2 infection and may serve as a biomarker of such an infection.

\section{Potassium}

Hypokalemia can increase ARDS and acute cardiac injury risk, which is considered the most commonly occurring complication in COVID-19. The literature demonstrated that SARS-CoV-2 binds to ACE2 and reduces its expression; consequently, angiotensin-II increases, which subsequently leads to hypokalemia. (Alwaqfi and Ibrahim 2020). COVID19 patients showed increased concentration of plasma angiotensin-II, possibly responsible for acute lung injury and as confirmed in SARS-CoV animal models (Zemlin and Wiese 2020). A pooled analysis reported that potassium concentration is significantly lower in severe COVID-19 patients than non-severe patients with substantially less heterogeneity than observed for sodium. (Lippi et al. 2020). As with low sodium, reduced plasma potassium levels may be a marker of SARS-CoV-2 infection.

\section{Calcium}

Calcium plays an essential role in making our bones stronger, but it also works against invading viruses by eliminating them out from the cells. Hence, calcium ion protects from the common cold. A joint analysis reported a lower calcium concentration in critical COVID-19 patients than those with less severe disease and concludes that serum calcium level in patients is inversely proportional to the severity of the disease (Rodriguez-Morales et al. 2020). As with low sodium and potassium, hypocalcemia may serve as a marker of the severity of a SARS-CoV-2 infection.

\section{Phosphorus}

Phosphorus is involved in making protein for the growth, maintenance, and repair of cells and tissues (Vance 2011). A retrospective study of the clinical data of the coronavirus 2019 showed decreased phosphorus levels in COVID19 patients. This study suggests that hypophosphatemia is directly proportional to the severity of COVID-19; monitoring the serum phosphorus level in COVID-19's severe/critical patients is proved to be beneficial for prognosis (Xue et al. 2020). During coronavirus entry into the body, the decreased phosphorus level increases the risk of proneness to the infections. This virus, when it enters the body through ACE- 2 receptors, our body activates innate immune responses against the viral infection. But due to the low availability of minerals, phosphorus mainly weakens immune responses and thus cannot recover the damage to the cells and tissues, leading to disease progression. This gives insight into the possible role of phosphorus in the prevention of COVID-19 causalities. Further, there is a need to understand the pathological mechanisms involved in hypophosphatemia related to COVID-19 infections (Ni et al. 2020). A clinical study may be needed to show the benefit of restoring low phosphate levels in SARS-CoV-2 patients.

\section{Magnesium (Mg)}

Magnesium is the forgotten cation. Mg supplementation might reveal very useful in managing the stress triggered by the pandemic and the post-traumatic stress disorder that will plague COVID-19's survivors, health professionals, and common people. It also plays a significant role in immune function by regulating various functions such as immune cell adherence, immunoglobulin synthesis, binding of Immunoglobulin M (IgM) lymphocyte, antibody-dependent cytolysis, and macrophage response towards lymphokines (Ni et al. 2020). However, some in vitro and in vivo studies suggest that magnesium plays a vital role in the immune response against viral infections (Jayawardena et al. 2020). In Singapore, a cohort study reported that the combination of vitamin $\mathrm{D}$, magnesium, and vitamin B12 (DMB) could reduce the progression rate in older patients with COVID-19. Vitamin B12 (1000 IU) and magnesium $(150 \mathrm{mg}$ ) have a protective effect against respiratory tract infection and reduce proinflammatory cytokines. A double-blind, randomized trial is suggested. (Tan et al. 2020). 


\section{Role of micro minerals in COVID-19}

During this pandemic COVID-19, preventive measures suggested by medical practitioners and scientists generally underline the significant role of immunity as a potential weapon against COVID-19. Till now, no WHO-approved treatment is available to cure the disease; hence an efficient and healthy immune system is the only defense against this viral infection (Ashour et al. 2020; Cascella et al. 2020). Indeed, trace elements are the essential micronutrients having a significant role in immunity. Apart from immunomodulatory action, trace elements such as copper, zinc, manganese, selenium, etc., show antiviral activity by inhibiting virus replication in host cells. The antioxidant properties of trace elements improvise the immune response and make alterations in the viral genome. Trace elements are involved in multiple immunomodulatory pathways and improvise the defense system of the body by a different mechanism (Calder 2020; Zabetakis et al. 2020).

\section{Zinc (Zn)}

Biological function Zinc is an important element of nutritional immunity and plays a versatile role in the biological system. Apart from its active involvement in lipid metabolism and carbohydrate regulation, $\mathrm{Zn}$ is responsible for the cardiovascular, reproductive, and nervous systems (Collins 2016).

Various pieces of evidence reveal that zinc shows antiviral property and plays an essential role in immunity. Zinc was reported as an active agent for immunity against H1N1 influenza. (Sandstead and Prasad 2010). Mechanistically, like SARS-CoV, the pathogenesis of SARS-CoV-2 is also based upon angiotensin-converting enzyme 2 (ACE2), which allows virus entry into the host's cell. Therefore, ACE2 is considered the most promising therapeutic target for the treatment of COVID-19 (Zhang et al. 2020a, b). Evidence reveals the decline in the activity of ACE2 in rat lungs after $\mathrm{Zn}^{2+}$ treatment (Chilvers et al. 2001). Furthermore, in vitro data demonstrate that $\mathrm{Zn}^{2+}$ cation allows the inhibition of SARS-coronavirus RNA polymerase by suppressing its replication (Te Velthuis et al. 2010), hence show antiviral activity. All these pieces of evidence and arguments strongly favor that zinc supplementation might support adjuvant therapy in COVID-19 treatment (Zhang et al. 2018). A randomized, double-blind study is suggested.

\section{Iron (Fe)}

Biological function Iron plays a versatile role in the biological system. Despite being an oxidant, iron plays a significant role in hemoglobin and red blood cell production.
Role in COVID-19 Recent evidence reveals that apart from pulmonary involvement and elevation in IL-6, COVID19 patients display a broader spectrum of hyperinflammatory syndromes distinguished by cytokine release syndrome (CRS), such as secondary haemophagocytic lymphohistiocytosis (sHLH). Hyperferritinemia is the primary feature of these syndromes, which plays a significant role in inflammation. These findings support the theory that the acute phase of SARS-CoV-2 infection induces ferritin production associated with the rapid onset of inflammation. Hence, ferritin's immunomodulatory effects contribute to the formation of reactive oxygen species (ROS) and lead to tissue damage. With this contrast, iron chelation therapy is represented as the novel approach against COVID-19. Iron chelation therapy is the most effective approach in a wide spectrum of diseases associated with iron overload. Therefore, iron chelation therapy is considered an appropriate approach to improve survival in COVID-19 patients. A randomized, double-blind clinical trial should be considered.

\section{Copper (Cu)}

Biological function Copper is enlisted as the essential micronutrient for humans against viral infections. After absorption in the small intestine, dietary $\mathrm{Cu}$ enters the systemic circulation and involves many biological processes to maintain the body's average ionic balance (Osredkar and Sustar 2011).

Role in COVID-19 Cu is involved in B cells' normal functioning, $\mathrm{T}$ helper cells, macrophages, and natural killer (NK) cells, also involved in cell-mediated immunity, encounter infamous microbes, and produce antibodies against the pathogen (Raha et al. 2020). Studies reveal that Cu's exposure to coronavirus 229E damage the viral genome and impact viral morphology irreversibly (Warnes et al. 2015). Furthermore, $\mathrm{Cu}$ processes the potential to neutralize infectious viruses such as poliovirus, bronchitis virus, human immunodeficiency virus type 1 (HIV-1), and boost immunity. These studies reflect the sensitivity of viral infection towards $\mathrm{Cu}$; hence, copper supplement may be a better treatment approach for COVID-19 patients (Raha et al. 2020).

\section{Selenium (Se)}

Biological function For multiple reasons, Se is considered the most reliable trace element due to its antiviral and antiinflammatory properties. Distinct sets of selenoproteins regulate the normal functioning of the immune system comprised of selenocysteine. Deficiency of Se established severe risk factors for viral infections (Guillin et al. 2019).

Role in COVID-19 Data from China link the cured rate of COVID-19 patients in association with the body's basal 
selenium status (Zhang and Liu 2020). Studies reveal that glutathione peroxidase 1 (GPX1) is the cytosolic selenoenzyme activated by Se and responsible for the antiviral property. Data reveal that multiple sets of selenoproteins like GPX1 potentially counterbalance the oxidative stress level and inflammation induced by SARS-CoV-2 (Seale et al. 2020). This evidence suggests the crucial role of Se-based mechanisms in SARS-CoV-2; hence it can be concluded that a high intake of nutritional selenium has a significant impact on SARS-CoV-2 infection.

\section{Manganese (Mn)}

Biological function Being an essential trace element, nutritional manganese has various effects on the biological system. Mn possesses antioxidant activity and responsible energy production by the amino acid breakdown (Sigel 2000).

Role in COVID-19 In an emerging approach towards the treatment of COVID-19, various sherds of evidence reveal Mn's immunomodulatory and antiviral action. The experimental data indicate that the hepatitis- $\mathrm{B}$ virus' protein priming depends upon the concentration of manganese ion; hence, it acts as a potent antiviral agent (Yao et al. 2009). Evidence also suggests impaired antibody production as a response to Mn deficiency, highlighting its crucial role in promoting immunity (Haase 2018). All this evidence indicates the supportive role of nutritional Mn in COVID-19 treatment.

\section{lodine (I)}

Biological function Iodine is a widely used trace element, especially for therapeutic purposes. Biologically, iodine is a mineral responsible for producing thyroid hormones and plays a significant metabolic role in the body. Iodine also plays an important role in neurodevelopment during pregnancy (Venturi et al. 2000).

Role in COVID-19 According to previous reports, iodinebased products like povidone-iodine (PVP-I) are highlighted as potent chemical agents against SARS-CoV. Evidence reveals that such iodine-based compounds are equally efficient to $70 \%$ ethanol. Hence, it can be used as a disinfectant against SARS-CoV-2, used for handwashing, disinfecting medical instruments, gargling, spraying the throat, and other external uses (Kariwa et al. 2006). In in vivo systems, iodine also plays an essential role as antiviral in respiratory mucosa, saliva, and airways. Evidence reveals the augmentation of innate antiviral immunity upon iodine delivery to airway mucosa (Fischer et al. 2011). Furthermore, a high dose of iodide supplement reduces the risk of severity in the respiratory syncytial virus and improves mucosal oxidative defenses (Turkia 2020). Iodine's external and internal applications make it a feasible candidate to be used as supportive therapy in SARS-CoV-2 infection.

\section{Cobalt (Co)}

Biological function Biologically, vitamin B12 is a cobaloxime responsible for maintaining the nervous system and producing red blood cells (RBC). Nutritional Co is an essential mineral responsible for blood formation. (Chaturvedi et al. 2004).

Role in COVID-19 Study reveals that cobalt (III), upon complex with a tetra-azamacrocyle chelator, hydrolyzes phosphodiester bonds in viral DNA and RNA. Furthermore, its high affinity towards RNA template inhibits the RNA translation and is responsible for therapeutic effects against several viral infections such as hepatitis virus, sindbis virus, herpes simplex virus, and Epstein-Barr virus (Chang et al. 2010). Their therapeutic activities against a wide range of viral infections indicate its role as supportive therapy in COVID-19 treatment and a double-blind placebo-controlled study may be warranted.

\section{Sulfur (S)}

Biological function Sulfur is responsible for producing essential amino acids such as cysteine and methionine, which plays a significant role in biocatalytic processes and other events like transport across cell membranes, immune functions, and blood clotting (Dutta et al. 2009).

Role in COVID-19 Evidence reveals that the sulfate-based compound like sodium thiosulfate possesses therapeutic efficacy for lungs and respiratory infection. Furthermore, clinical data demonstrate that sodium thiosulfate successfully ameliorates pneumonia and lung injury in adults and children. Based on multiple therapeutic roles and the respiratory system's involvement, sulfur might show a protective effect against COVID-19 (Evgen'ev et al. 2020).

\section{Lay summary and conclusion}

The possible therapeutic benefits of vitamins A, B, C, D, $\mathrm{E}$, and $\mathrm{K}$ via immunomodulation in COVID-19 patients have been evaluated and analyzed based on available evidence. Trace elements such as zinc, selenium, manganese, and copper, are essential micronutrients. Antiviral and antioxidant properties are involved in multiple immunomodulatory pathways and improve the body's defence system by different mechanisms. Supplementation of vitamins and 
micronutrients may have a positive impact on the recovery of COVID-19 infection. However, there is a lack of preclinical and clinical studies associated with vitamins and micronutrients in the management of COVID-19. To explore the possible beneficial role of vitamins and micronutrients in COVID-19 patients, various clinical studies are being carried out. By reviewing various studies, it can be concluded that adequate supplementation of vitamins and micronutrients should be considered to improve SARS- CoV infection outcomes. The current situation has resulted in several highly effective vaccines, and work is being conducted for targeted drug therapy; these are very expensive and complicated processes with a narrow spectrum targeted activity. In contrast, vitamin and micronutrient supplementation is a relatively cost-efficient and easy approach when supported by robust clinical studies, and has possible broadspectrum activity and potentially long-term health benefits. While considering the health benefit and risk ratio, vitamin and micronutrients are probably justifiable with negligible risks. This is in contrast with the risk associated with novel drugs and some vaccines. Therefore, nutrient supplementations seem to be a promising approach towards SARS-CoV infection.

Acknowledgements Authors are thankful to Science and Engineering Board (SERB), Department of Science and Technology, Govt. of India, New Delhi, for providing financial assistance under Core Research Grant (DST-SERB-CRG) to Dr. Puneet Kumar. The Senior Research Fellowship to Mr. Narhari Gangaram Yedke under this scheme is also highly acknowledged.

Author contributions All authors contributed equally in the writing of the manuscript.

Funding No special funding for the manuscript was received.

\section{Declarations}

Conflict of interest The authors have no conflict of interest.

\section{References}

Alwaqfi NR, Ibrahim KS (2020) COVID-19: an update and cardiac involvement. J Cardiothorac Surg 15(1):1-6. https://doi.org/10. 1186/s13019-020-01299-5

Angulo A, Chandraratna RA, LeBlanc JF, Ghazal P (1998) Ligand induction of retinoic acid receptors alters an acute infection by murine cytomegalovirus. J Virol 72(6):4589-4600. https://doi. org/10.1128/JVI.72.6.4589-4600.1998

Ashour HM, Elkhatib WF, Rahman M, Elshabrawy HA (2020) Insights into the recent 2019 novel coronavirus (SARS-CoV-2) in light of past human coronavirus outbreaks. Pathogens 9(3):186. https:// doi.org/10.3390/pathogens9030186

Baladia E, Pizarro AB, Rada G (2020) Vitamin C for the treatment of COVID-19: a living systematic review. medRxiv. https://doi.org/ $10.1101 / 2020.04 .28 .20083360$
Calder PC (2020) Nutrition, immunity, and Covid-19. BMJ Nutr Prev Heal Bmjnph. https://doi.org/10.1136/bmjnph-2020-000085

Calder PC et al (2020) Optimal nutritional status for a well-functioning immune system is an important factor to protect against viral infections. Nutrients. https://doi.org/10.3390/nu12041181

Cannell JJ, Vieth R, Umhau JC, Holick MF, Grant WB, Madronich S, Garland CF, Giovannucci E (2006) Epidemic influenza and vitamin D. Epidemiol Infect 134(6):1129-1140. https://doi.org/ $10.1017 /$ S0950268806007175

Carr AC (2020) A new clinical trial to test high-dose vitamin C in patients with COVID- 19. Crit Care 24(1):1-2. https://doi.org/ 10.1186/s13054-020-02851-4

Carr AC, Maggini S (2017) Vitamin C, and immune function. Nutrients 9(11):1211. https://doi.org/10.3390/nu9111211

Cascella M, Rajnik M, Cuomo A, Dulebohn SC, Di Napoli R (2020) Features, evaluation and treatment coronavirus (COVID-19). In: Statpearls [internet]. StatPearls Publishing

Chang EL, Simmers C, Knight DA (2010) Cobalt complexes as antiviral and antibacterial agents. Pharmaceuticals 3(6):1711-1728. https://doi.org/10.3390/ph3061711

Chaturvedi UC, Shrivastava R, Upreti RK, 2004. Viral infections and trace elements: a complex interaction. Curr Sci 1536-54. https:// www.jstor.org/stable/24109032

Cole-Jeffrey CT, Liu M, Katovich MJ, Raizada MK, Shenoy V (2015) ACE2, and microbiota: emerging targets for cardiopulmonary disease therapy. J Cardiovasc Pharmacol 66(6):540

Collins JF (2016) Molecular, genetic, and nutritional aspects of major and trace minerals. Academic Press

Colunga Biancatelli RML, Berrill M, Marik PE (2020) The antiviral properties of vitamin C. Taylor \& Francis. https://doi.org/10. 1080/14787210.2020.1706483

Derbyshire E, Delange J (2020) COVID-19: is there a role for immunonutrition, particularly in the over $65 \mathrm{~s}$ ? BMJ Nutrition, Prevention \& Health 3(1):100-105. https://doi.org/10.1136/ bmjnph-2020-000071

Dey S, Bishayi B (2018) Killing of S. aureus in murine peritoneal macrophages by ascorbic acid along with antibiotics chloramphenicol or ofloxacin: correlation with inflammation. Microb Pathog 115:239-250. https://doi.org/10.1016/j.micpath.2017.12.048

Dutta PK, Keller J, Yuan Z, Rozendal RA, Rabaey K (2009) Role of sulfur during acetate oxidation in biological anodes. Environ Sci Technol 43(10):3839-3845. https://doi.org/10.1016/j.micpath. 2017.12.048

Ekert PG, Vaux DL (1997) Apoptosis and the immune system. Br Med Bull 53(3):591-603. https://doi.org/10.1093/oxfordjournals.bmb. a011632

Evgen'ev MB, Frenkel A (2020) Possible application of H2S-producing compounds in the therapy of coronavirus (COVID-19) infection and pneumonia. Cell Stress Chaperones, pp 1-3

Fischer AJ, Linnemann NJ, Krishnamurthy S, Pócza P, Durairaj L, Launspach JL et al (2011) Enhancement of respiratory mucosal antiviral defenses by the oxidation of iodide. Am J Respir Cell Mol Biol 45(4):874-881

Frieman M, Yount B, Heise M, Kopecky-Bromberg SA, Palese P, Baric RS (2007) Severe acute respiratory syndrome coronavirus ORF6 antagonizes the STAT1 function by sequestering nuclear import factors on the rough endoplasmic reticulum/Golgi membrane. J Virol 81(18):9812-9824. https://doi.org/10.1128/JVI.01012-07

Furuya A, Uozaki M, Yamasaki H, Arakawa T, Arita M, Koyama AH (2008) Antiviral effects of ascorbic and dehydroascorbic acids in vitro. Int J Mol Med 22(4):541-545. https://doi.org/10.3892/ ijmm 00000053

Gheblawi $\bar{M}$, Wang K, Viveiros A, Nguyen Q, Zhong J-C, Turner AJ et al (2020) Angiotensin-converting enzyme 2: SARS-CoV-2 receptor and regulator of the renin-angiotensin system: celebrating the 20th anniversary of the discovery of ACE2. Circ Res 
10:1456-1474. https://doi.org/10.1161/CIRCRESAHA.120. 317015

Gombart AF, Pierre A, Maggini S (2020) A review of micronutrients and the immune system-working in harmony to reduce the risk of infection. Nutrients. https://doi.org/10.3390/nu12010236

Gudas LJ (2012) Emerging roles for retinoids in regeneration and differentiation in normal and disease states. Biochim Biophys Acta (BBA)-Molecular Cell Biol Lipids. 1821(1):213-21. https://doi. org/10.1016/j.bbalip.2011.08.002.

Guillin OM, Vindry C, Ohlmann T, Chavatte L (2019) Selenium, selenoproteins and viral infection. Nutrients 11(9):2101. https://doi. org/10.3390/nu11092101

Haase H (2018) Innate immune cells speak manganese. Immunity 48(4):616-618. https://doi.org/10.1016/j.immuni.2018.03.031

Habib MB, Sardar S, Sajid J (2020) Acute symptomatic hyponatremia in setting of SIADH as an isolated presentation of COVID-19. IDCases. e00859

Han JE, Jones JL, Tangpricha V, Brown MA, Hao L, Hebbar G et al (2016) High dose vitamin D administration in ventilated intensive care unit patients: a pilot double blind randomized controlled trial. J Clin Transl Endocrinol 4:59-65. https://doi.org/10.1016/j. jcte.2016.04.004

Heikkinen T, Järvinen A (2003) The common cold. Lancet 361(9351):51-59. https://doi.org/10.1016/S0140-6736(03) $12162-9$

Hemila H (2016) Vitamin E administration may decrease the incidence of pneumonia in elderly males. Clin Interv Aging 11:1379-1385. https://doi.org/10.2147/CIA.S114515

Hemilä H, Chalker E (2013) Vitamin C for preventing and treating the common cold. Cochrane database Syst Rev. https://doi.org/ 10.1002/14651858.CD000980.pub4

Hemilä H, Chalker E (2019) Vitamin C can shorten the length of stay in the ICU: a meta-analysis. Nutrients 11(4):708. https://doi. org/10.1002/14651858.CD000980.pub4

Herr C, Shaykhiev R, Bals R (2007) The role of cathelicidin and defensins in pulmonary inflammatory diseases. Expert Opin Biol Ther 7(9):1449-1461. https://doi.org/10.3390/nu110 40708

Hu Y, Li W, Gao T, Cui Y, Jin Y, Li P et al (2017) The severe acute respiratory syndrome coronavirus nucleocapsid inhibits type I interferon production by interfering with TRIM25- mediated RIG-I ubiquitination. J Virol. https://doi.org/10.3390/v13010047

Huang C, Wang Y, Li X, Ren L, Zhao J, Hu Y et al (2020) Clinical features of patients infected with 2019 novel coronavirus in Wuhan. China Lancet 395(10223):497-506. https://doi.org/10. 1016/S0140-6736(20)30183-5

Hubicka U, Padiasek A, Żuromska-Witek B, Szlósarczyk M (2020) Determination of Vitamins K1, K2 MK-4, MK-7, MK-9 and D3 in pharmaceutical products and dietary supplements by TLCDensitometry. Processes 8(7):870. https://doi.org/10.1021/jf204 $194 \mathrm{z}$

Hughes DA, Norton R (2009) Vitamin D and respiratory health. Clin Exp Immunol 158(1):20-25. https://doi.org/10.1111/j.13652249.2009.04001.x

Ivanov V, Ivanova S, Niedzwiecki A, Rath M, Niedzwiecki A (2020) Effective and safe global public health strategy to fight the COVID-19 pandemic: Specific micronutrient composition inhibits Coronavirus cell-entry receptor (ACE2) expression. https:// doi.org/10.1056/NEJMoa2015432

Janssen R, Walk J (2020) Vitamin K epoxide reductase complex subunit 1 (VKORC1) gene polymorphism as determinant of differences in Covid-19-related disease severity. Med Hypotheses 144:110218. https://doi.org/10.1016/j.mehy.2020.110218

Jayawardena R, Sooriyaarachchi P, Chourdakis M, Jeewandara C, Ranasinghe P (2020) Enhancing immunity in viral infections, with special emphasis on COVID-19: A review. Diabetes
MetabSyndr Clin Res Rev. https://doi.org/10.1016/j.dsx.2020. 04.015

Kariwa H, Fujii N, Takashima I (2006) Inactivation of SARS coronavirus by means of povidone-iodine, physical conditions and chemical reagents. Dermatology 212(Suppl. 1):119-123. https:// doi.org/10.1159/000089211

Kashiouris MG, L'Heureux M, Cable CA, Fisher BJ, Leichtle SW (2020) The emerging role of vitamin $C$ as a treatment for sepsis. Nutrients 12(2):292. https://doi.org/10.3390/nu12020292

Klok FA, Kruip MJHA, van der Meer NJM, Arbous MS, Gommers DAMPJ, Kant KM et al (2020) Incidence of thrombotic complications in critically ill ICU patients with COVID-19. Thromb Res 191:145. https://doi.org/10.1016/j.thromres.2020.04.013

Kraft CE, Angert ER (2017) Competition for vitamin B1 (thiamin) structures numerous ecological interactions. Q Rev Biol 92(2):151-168. https://doi.org/10.1002/open.201600160

Kumar V, Jena M (2020) In silico virtual screening-based study of nutraceuticals predicts the therapeutic potentials of folic acid and its derivatives against COVID-19. https://doi.org/10.1007/ s13337-020-00643-6

Laaksi I (2012) Vitamin D and respiratory infection in adults. Proc Nutr Soc 71(1):90-97

Lee GY, Han SN (2018) The role of vitamin E in immunity. Nutrients. MDPI AG. https://doi.org/10.5281/zenodo.3990659

Lei G-S, Zhang C, Cheng B-H, Lee C-H (2017) Mechanisms of action of vitamin D as supplemental therapy for Pneumocystis pneumonia. Antimicrob Agents Chemother. https://doi.org/10.3390/ antiox 9070624

Lemire JM (1992) Immunomodulatory role of 1, 25- dihydroxyvitamin D3. J Cell Biochem (1):26-31. https://doi.org/10.1016/ 0960-0760(95)00106-a

Li B, Wang Y, Shen F, Wu M, Li Y, Fang Z, et al (2018) Identification of retinoic acid receptor agonists as potent hepatitis $\mathrm{B}$ virus inhibitors via a drug repurposing screen. Antimicrob Agents Chemother. https://doi.org/10.1016/j.antiviral.2019.04.009

Lindner DJ, Borden EC, Kalvakolanu DV (1997) Synergistic antitumor effects of a combination of interferons and retinoic acid on human tumor cells in vitro and in vivo. Clin Cancer Res 3(6):931-937

Lindschinger M, Tatzber F, Schimetta W, Schmid I, Lindschinger B, Cvirn G, Stanger O, Lamont E, Wonisch W (2019) A randomized pilot trial to evaluate the bioavailability of natural versus synthetic Vitamin B complexes in healthy humans and their effects on homocysteine, oxidative stress, and antioxidant levels. Oxid Med Cell Longev. https://doi.org/10.1155/2019/6082613

Lippi G, South AM, Henry BM (2020) Electrolyte imbalances in patients with severe coronavirus disease 2019 (COVID-19). Ann Clin Biochem 57(3):262-265

Liu B, Li M, Zhou Z, Guan X, Xiang Y (2020) Can we use interleukin-6 (IL-6) blockade for coronavirus disease 2019 (COVID19)-induced cytokine release syndrome (CRS)? J Autoimmunity. https://doi.org/10.1016/j.jaut.2020.102452

Luo XM, Ross AC (2006) Retinoic acid exerts dual regulatory actions on the expression and nuclear localization of interferon regulatory factor-1. Exp Biol Med 231(5):619-31. https://doi.org/10.1 $177 \% 2 F 153537020623100517$

Luo Y, Li Y, Dai J, 2020. Low blood sodium increases risk and severity of COVID-19: a systematic review, meta-analysis and retrospective cohort study. medRxiv. https://doi.org/10.1101/2020.05.18. 20102509

Martineau AR, Jolliffe DA, Hooper RL, Greenberg L, Aloia JF, Bergman P, Dubnov-Raz G, Esposito S, Ganmaa D, Ginde AA, Goodall EC (2017) Vitamin D supplementation to prevent acute respiratory tract infections: systematic review and meta-analysis of individual participant data. BMJ. https://doi.org/10.1136/bmj. i6583 
Martínez-Moreno J, Hernandez JC, Urcuqui-Inchima S (2020) Effect of high doses of vitamin D supplementation on dengue virus replication, Toll-like receptor expression, and cytokine profiles on dendritic cells. Mol Cell Biochem.464(1-2):169-180. https:// doi.org/10.1007/s11010-019-03658-w

Matikainen S, Ronni T, Hurme M, Pine R, Julkunen I (1996) Retinoic acid activates interferon regulatory factor- 1 gene expression in myeloid cells

Mccann JC, Ames BN (2020) Vitamin K, an example of triage theory: is micronutrient inadequacy linked to diseases of aging? 1-3. https://doi.org/10.3945/ajen.2009.27930

Mehmel M, Jovanović N, Spitz U (2020) Nicotinamide ribosidethe current state of research and therapeutic uses. Nutrients 12(6):1616. https://doi.org/10.3390/nu12061616

Meydani SN, Lewis ED, Wu D (2018) Perspective: Should vitamin E recommendations for older adults be increased? Adv Nutr 9(5):533-543

Michienzi SM, Badowski ME (2020) Can vitamins and/or supplements provide hope against coronavirus? Drugs in Context 9:1-29. https://doi.org/10.7573/dic.2020-5-7

Mikkelsen K, Apostolopoulos V (2019) Vitamin B1, B2, B3, B5, and B6 and the immune system. In: Nutrition and immunity. Springer, Cham, pp 115-125. https://doi.org/10.1007/ 978-3-030-16073-9_7

Nagai A, Matsumiya H, Hayashi M, Yasui S, Okamoto H, Konno K (1994) Effects of nicotinamide and niacin on bleomycin-induced acute injury and subsequent fibrosis in hamster lungs. Experimentallungresearch 20(4):263-281. https://doi.org/10.3109/ 01902149409064387

Ni W, Yang X, Yang D, Bao J, Li R, Xiao Y et al (2020) Role of angiotensin-converting enzyme 2 (ACE2) in COVID-19. Crit Care 24(1):1-10. https://doi.org/10.1186/s13054-020-03120-0

Osredkar J, Sustar N (2011) Copper and zinc, biological role and significance of copper/zinc imbalance. J Clin Toxicol s 3(2161):495. https://doi.org/10.4172/2161-0495.S3-001

Parra M, Stahl S, Hellmann H (2018) Vitamin B6 and its role in cell metabolism and physiology. Cells 7(7):84. https://doi.org/10. 3390/cells7070084

Raha S, Mallick R, Basak S, Duttaroy AK (2020) Is copper beneficial for COVID-19 patients? Med Hypotheses. https://doi.org/10. 1016/j.mehy.2020.109814

Raverdeau M, Mills KHG (2014) Modulation of T cell and innate immune responses by retinoic acid. J Immunol 192(7):29532958. https://doi.org/10.4049/jimmunol.1303245

Rodriguez-Morales AJ, Cardona-Ospina JA, Gutiérrez-Ocampo E, Villamizar-Peña R, Holguin-Rivera Y, Escalera-Antezana JP, et al. (2020) Clinical, laboratory and imaging features of COVID-19: A systematic review and meta-analysis. Travel Med Infect Dis. https://doi.org/10.1016/j.tmaid.2020.101623

Romita K, O'Brien R. Minerals: Their functions and sources. Heal Inc. 2018. Rondanelli M, Miccono A, Lamburghini S, Avanzato I, Riva A, Allegrini P, et al (2018) Self-care for common colds: the pivotal role of vitamin D, vitamin C, zinc, and echinacea in three main immune interactive clusters (physical barriers, innate and adaptive immunity) involved during an episode of common colds-practical advice on dosages an. Evidence-Based Complement Altern Med. https://doi.org/10.1155/2018/5813095

Rothan HA, Byrareddy SN. 2020. The epidemiology and pathogenesis of coronavirus disease (COVID-19) outbreak. J Autoimmun. https://doi.org/10.1016/j.jaut.2020.102433

Sabetta JR, DePetrillo P, Cipriani RJ, Smardin J, Burns LA, Landry ML (2010) Serum 25- hydroxyvitamin d and the incidence of acute viral respiratory tract infections in healthy adults. PLoS ONE 5(6):e11088. https://doi.org/10.1371/journal.pone.0011088

Sajadi MM, Habibzadeh P, Vintzileos A, Shokouhi S, Miralles-Wilhelm F, Amoroso A et al (2020) Latitude Analysis to Predict
Potential Spread and Seasonality for COVID-19. Available SSRN 3550308

Sandstead HH, Prasad AS (2010) Zinc intake and resistance to H1N1 influenza. Am J Public Health 100(6):970. https://doi.org/10. 2105/AJPH.2009.187773

Seale LA, Torres DJ, Berry MJ, Pitts MW (2020) A role for selenium-dependent GPX1 in SARS-CoV-2 virulence. Am J Clin Nutr.;112(2):447-8. https://doi.org/10.1093/ajen/nqaa177

Shakoor H, Feehan J, Dhaheri AS Al, Ali HI, Platat C, Ismail LC et al (2020a) Immune-boosting role of vitamins D, C, E, zinc, selenium and omega- 3 fatty acids: could they help against COVID19? Maturitas. https://doi.org/10.1016/j.maturitas.2020.08.003

Shakoor H, Feehan J, Mikkelsen K, Al Dhaheri AS, Ali HI, Platat C, Ismail LC, Stojanovska L, Apostolopoulos V (2020b) Be well: a potential role for vitamin B in COVID-19. Maturitas. https:// doi.org/10.1016/j.maturitas.2020.08.007

Sharifi A, Vahedi H, Nedjat S, Rafiei H, Hosseinzadeh- Attar MJ (2019) Effect of single-dose injection of vitamin D on immune cytokines in ulcerative colitis patients: a randomized placebocontrolled trial. APMIS 127(10):681-687. https://doi.org/10. 1111/apm.12982

Sheybani Z, Dokoohaki MH, Negahdaripour M, Dehdashti M, Zolghadr H, Moghadami M, Masoompour SM, Zolghadr AR (2020) The role of folic acid in the management of respiratory disease caused by COVID-19

Shibata N, Kunisawa J, Kiyono H (2017) Dietary and microbial metabolites in the regulation of host immunity. Front Microbiol 8:2171. https://doi.org/10.3389/fmicb.2017.02171

Sigel H (2000) Metal ions in biological systems: manganese and its role in biological processes, vol 37. CRC press

Spiegel M, Pichlmair A, Martínez-Sobrido L, Cros J, García-Sastre A, Haller $\mathrm{O}$ et al (2005) Inhibition of beta interferon induction by severe acute respiratory syndrome coronavirus suggests a twostep model for activation of interferon regulatory factor 3. J Virol 79(4):2079-2086. https://doi.org/10.1128/JVI.79.4.2079-2086. 2005

Spinas E, Saggini A, Kritas SK, Cerulli G, Caraffa A, Antinolfi P (2015) Crosstalk between vitamin B and immunity. J Biol Regul Homeost Agents 29(2):283-288

Tan CW, Ho LP, Kalimuddin S, Cherng BPZ, Teh YE, Thien SY et al (2020) A cohort study to evaluate the effect of combination Vitamin D, Magnesium and Vitamin B12 on progression to severe outcome in older COVID-19 patients. Nutrition. https://doi.org/ $10.1101 / 2020.06 .01 .20112334$

Tay MZ et al (2020) Inflammation and intervention, pp 363-374

Te Velthuis AJW, van den Worm SHE, Sims AC, Baric RS, Snijder EJ, van Hemert MJ (2010) Zn2+ inhibits coronavirus and arterivirus RNA polymerase activity in vitro and zinc ionophores block the replication of these viruses in cell culture. PLoS Pathog 6(11):e1001176. https://doi.org/10.1371/journ al.ppat. 1001176

Trottier C, Chabot S, Mann KK, Colombo M, Chatterjee A, Miller WH Jr et al (2008) Retinoids inhibit measles virus in vitro via nuclear retinoid receptor signaling pathways. Antiviral Res 80(1):45-53. https://doi.org/10.1016/j.antiviral.2008.04.003

Turkia M (2020) COVID-19 and iodide. Available at SSRN 3585989

Ueland PM, McCann A, Midttun Ø, Ulvik A (2017) Inflammation, vitamin B6 and related pathways. Mol Aspects Med 53:10-27. https://doi.org/10.1016/j.mam.2016.08.001

Vance CP (2011) Phosphorus as a critical macronutrient. In: The molecular and physiological basis of nutrient use efficiency in crops. Wiley-Blackwell, Chichester, pp 229-264. https://doi.org/ 10.1002/9780470960707

Venturi S, Donati FM, Venturi M, Venturi A, Grossi L, Guidi A (2000) Role of iodine in evolution and carcinogenesis of thyroid, breast and stomach. Adv Clin Pathol 4:11-18 
Verhagen H, Buijsse B, Jansen E, Bueno-De-Mesquita B (2006) The state of antioxidant affairs. Nutrition Today 4:244-252

Booth L S. Vitamin K: food composition and dietary intakes, 2012. Food \& nutrition research. 56(1):5505.https://doi.org/10.3402/ fnr.v56i0.5505

Warnes SL, Little ZR, Keevil CW (2015) Human coronavirus 229E remains infectious on common touch surface materials. MBio. https://doi.org/10.1128/mBio.01697-15

Wimalawansa SJ (2020) Global epidemic of coronavirus - Covid-19: What can we do to minimize risks. Eur J Biomed 7(3):432-438

Xu J, Yang J, Chen J, Luo Q, Zhang Q, Zhang H (2017) Vitamin D alleviates lipopolysaccharide- induced acute lung injury via regulation of the renin-angiotensin system. Mol Med Rep 16(5):74327438. https://doi.org/10.3892/mmr.2017.7546

Xue X, Ma J, Zhao Y, Zhao A, Liu X, Guo W et al (2020) Correlation between hypophosphatemia and the severity of Corona Virus Disease 2019 patients. medRxiv. https://doi.org/10.1101/2020. 03.27.20040816

Yang Y, Ye F, Zhu N, Wang W, Deng Y, Zhao Z et al (2015) Middle East respiratory syndrome coronavirus ORF4b protein inhibits type I interferon production through both cytoplasmic and nuclear targets. Sci Rep 5:17554. https://doi.org/10.1038/srep1 7554

Yao D, Li H, Gou Y, Zhang H, Vlessidis AG, Zhou H et al (2009) Betulinic acid-mediated inhibitory effect on hepatitis B virus by suppression of manganese superoxide dismutase expression. FEBS J 276(9):2599-2614. https://doi.org/10.1111/j.1742-4658. 2009.06988.x

Yazdanpanah F, Hamblin MR (2020) Since January 2020 Elsevier has created a COVID-19 resource centre with free information in English and Mandarin on the novel coronavirus COVID-19. The COVID-19 resource centre is hosted on Elsevier Connect, the company's public news and information ', (January)

Yoshii K, Hosomi K, Sawane K, Kunisawa J (2019) Metabolism of dietary and microbial vitamin $\mathrm{B}$ family in the regulation of host immunity. Front Nutr 6:48. https://doi.org/10.3389/fnut.2019. 00048
Yuan S, Chu H, Chan JF-W, Ye Z-W, Wen L, Yan B et al (2019) SREBP-dependent lipidomic reprogramming as a broad-spectrum antiviral target. Nat Commun 10(1):1-15. https://doi.org/ 10.1038/s41467-018-08015-X

Yuki K, Fujiogi M, Koutsogiannaki S (2020) COVID-19 pathophysiology: a review. In: Clinical immunology. Academic Press Inc., pp 108427. https://doi.org/10.1016/j.clim.2020.108427.

Zabetakis I, Lordan R, Norton C, Tsoupras A (2020) COVID-19: the inflammation link and the role of nutrition in potential mitigation. Nutrients 12(5):1466. https://doi.org/10.3390/nu12051466

Zemlin AE, Wiese OJ (2020) ANNALS EXPRESS: Coronavirus disease 2019 (COVID- 19) and the renin-angiotensin system: a closer look at angiotensin-converting enzyme 2 (ACE2). Ann Clin Biochem 0004563220928361

Zhang L, Liu Y (2020) Potential interventions for novel coronavirus in China: a systematic review. J Med Virol 92(5):479-490. https:// doi.org/10.1002/jmv.25707

Zhang Y, Zhou W, Yan J, Liu M, Zhou Y, Shen X et al (2018) A review of the extraction and determination methods of thirteen essential vitamins to the human body: an update from 2010. Molecules 23(6):1484. https://doi.org/10.3390/molecules23061484

Zhang H, Penninger JM, Li Y, Zhong N, Slutsky AS (2020a) Angiotensin-converting enzyme 2 (ACE2) as a SARS-CoV-2 receptor: molecular mechanisms and potential therapeutic target. Intensive Care Med 46(4):586-590. https://doi.org/10.1007/ s00134-020-05985-9

Zhang J, Taylor EW, Bennett K, Saad R, Rayman MP (2020b) Association between regional selenium status and reported outcome of COVID-19 cases in China. Am J Clin Nutr 111(6):1297-1299. https://doi.org/10.1093/ajcn/nqaa095

Publisher's Note Springer Nature remains neutral with regard to jurisdictional claims in published maps and institutional affiliations. 